\title{
THE RATE OF GROWTH OF PASTURES
}

By P. B. LYNCH, Field Crop Experimentalist, Department of Agriculture, Wellington.

The essential study in this paper is the examination of seasonal and yearly changes in the growth rate of pastures and pasture species in different districts, on different soils, and over a number of 'years. It is impossible to deal with all aspects of the subject adequately in the time available, and I have therefore not considered in detail how or why these growth rate changes occur, -but have confined: discussion to an analysis of the differences in pasture growth rate that exist in various parts of New Zealand. Again, because the measurement trials of the Department of Agriculture' have so far been restricted to the flat and easily rolling country, comparisons are available only between better-than-average pastures under better-than-average management in the more productive districts of New Zealand. With the possible exception of some of the trials in Canterbury, all the pastures concerned are or could have been made dominantly ryegrass and white clover.

\section{MEASUREMENT OF GROWTH RATE}

Trials considered in the last 10 years have been those conducted under the "enclosure" or "frame" technique (1) where growth temporarily protected from sheep grazing inside "enclosures" is mown and weighed. Subsequent to mowing. and weighing these enclosures are shifted around the' trial field, which is under normal grazing management. As a result no sward deterioration from mowing takes place.- Before 1940 most trials concerned were conducted under Hudson's "alternate mowing and grazing technique" (2).

The time interval between cutting dates varies with two types of trial. Where the major aim of the

(1) Lynch, P. B.: Methods of measuring the Production from Grasslands: N.Z. Journal of Sci. and Tech., Vol: 28, No. 6 (Sec. A.), p.p. 385-405, 1947.

(2) Hudson, A. W.: Measurement, of Pasture Production: I. A. B. Herbage Publication Series. Bull. 11, page 21 . 
experiment is simply the measurement of pasture growth rate- a regular time interval is maintained between cutting dates, usually one of 2 weeks. With overlapping "growth periods" estimation of growth rate changes in half-weekly intervals is possible. In the majority of trials, however, various treatment comparisons are made and the plots are cut at a comparable. stage of growth with varying time intervals between cutting dates. These trials are not satisfactory for detailed growth rate studies, but can be used to consider growth rate changes in approximately monthly intervals or in intervals of less than a month in periods of high, production, while seasonal and yearly figures are comparable with those from "rate of growth" trials with fixed intervals. between cutting dates. However, such agreement does not occur when the stage of growth of the pasture when cut is much greater than would be considered satisfactory under normal rotational. grazing with sheep.- Much higher production figures can be obtained when pastures are cut only when they carry a heavy growth of grass.

\section{USE OF GROWTH-RATE DATA}

Until a considerable amount of data relating to pasture growth rate is available the wide application of the results is not apparent. Amongst other things the figures have been used in the: estimation of the productivity of different soils, types of pasture swards, and-various districts ; in the study of supplementary feed provision in relation to periods when pasture growth is deficient; in estimating the frequency of low grassland production years in different districts ; in measuring the periods of maximum production of various pasture species and as a basis for animal nutrition studies of various types. Accurate pasture growth rate data are required as fundamental information for most pasture investigations.

\section{PERCENTAGE- DRY. MATTER CONTENT OF PASTURES}

All production figures -given in this paper are in pounds of dry matter of pasture herbage per acre. It is interesting. to note. the changes in percentage dry matter in fresh green herbage at various times of the year. Short green growth (not dry stalky material) at low production periods, particularly in 
the summer, has a markedly higher percentage dry matter-than green herbage at periods when growth. is rapid, such as the spring. months. The nutritive value of green herbage in the summer is generally high in comparison with that found at other times of the year.

A highly. significant relationship has been established between dry matter percentage of herbage and the yield per acre of that herbage, so that the percentage of dry matter varies inversely with the rate of growth. Regression equations from three trials considered were as follows:

( $\mathrm{Y}=$ percentage dry matter. $\mathrm{X}=\mathrm{tb}$ green herhage per acre

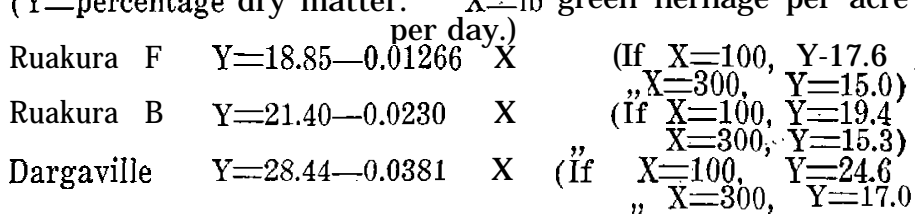

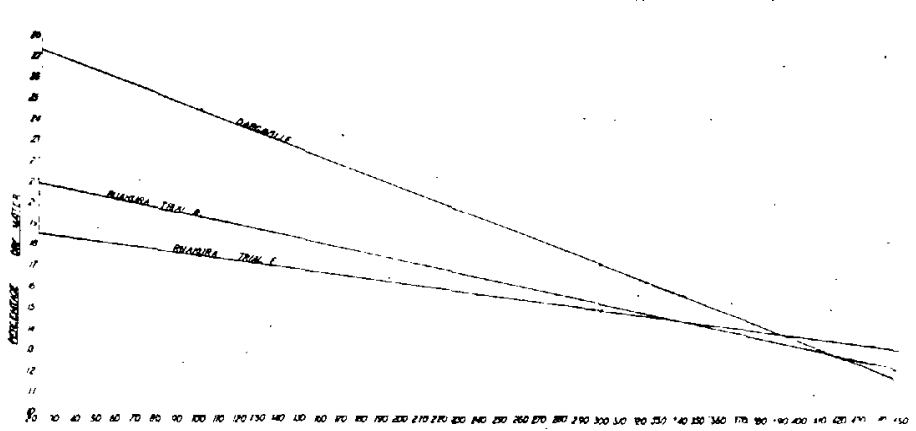

GRLIN HERBAGE - an

Graph 1.--Regression of dry mater percentagaes on green weight.

Graph 1 shows the slopes of the regression lines for the.above three trials.

Results from Trials :

(In the following tables results for the years 1940 to 1944 from Hamilton, and data from Kirwee, Wairoa, and Manutuke have been supplied by courtesy of the Director of the Animal Research Division).

\section{Pasture Growth Rate in Different Districts.}

The following list shows the pasture species and soil types of the trials considered. 
Dominant Pasture. Species and Soil, Types in Trials District Dominant: Species in Sward (in Soil, Type order of importance).

\begin{tabular}{|c|c|c|}
\hline $\begin{array}{l}\text { Hamilton } \\
\text { Marton } \\
\text { Stratford }\end{array}$ & $\begin{array}{l}\text { Perennial ryegrass : white clover. } \\
\text { Perennial ryegrass : white clover. } \\
\text { Perennial rvegrass : white clover: } \\
\text { sweet yernal: Yorkshire fog. }\end{array}$ & $\begin{array}{l}\text { Hamilton' clay loam. } \\
\text { Wanganui loam. } \\
\text { Stratford saindy loam. }\end{array}$ \\
\hline East Coast N.I. & $\begin{array}{l}\text { Perennial ryegrass: white clover } \\
\text { (some paspalum at Wairoa). }\end{array}$ & Alluvial loam: \\
\hline Winton & Perennial' ryegrass : white clover: & Silt loam \\
\hline Winchmore & $\begin{array}{l}\text { Perennial ryegrass, crested dogs- } \\
\text { tail, browntop, hairgrass, some } \\
\text { white, red, and subterranean } \\
\text { clovers. }\end{array}$ & y'loam over shingle. \\
\hline Le & Perennial ryegrass, cocksfoot, & Stony silt over shingle. \\
\hline -Kir & $\begin{array}{l}\text { Perennial ryegrass, red, white. } \\
\text { and subterranean clovers. }\end{array}$ & Chertsey silt loam. \\
\hline Haw & $\begin{array}{l}\text { Perennial ryegrass : white clover: } \\
\text { red clover: cocksfoot. }\end{array}$ & $\begin{array}{l}\text { Egmont silt loam: black } \\
\text { phase. }\end{array}$ \\
\hline Dargay & $\begin{array}{l}\text { Perennial ryegrass: paspalum } \\
\text { (varies with, season) with much } \\
\text { Yorkshire fog and white clover. }\end{array}$ & \\
\hline
\end{tabular}

Perennial ryegrass is the dominant species of all swards 'for which production figures. are analysed.

Table 1 summarises the mean yearly dry matter production from pastures at Hamilton, Stratford, Marton, Wairoa and Manutuke (East Coast, North Island) and Winton. In these districts trials have been in progress for a sufficient length of time to make the mean, figure of some value. The "East Coast N.I." figure is based on two years' results from Wairoa and four years' results from Manutuke; in both cases the trial area was on the alluvial flats and in somewhat comparable climates. No single trial is considered at Hamilton, Marton, and Winton, but in each of these districts the soil, pasture sward. and manurial treatment of the different trials from which data were taken are' comparable.

TABLE 1.

Mean yearly Dry Matter Production of Pastures ( If /acre) (Period : May-May).

\begin{tabular}{|c|c|c|c|c|}
\hline strict & No. of & Mean Yearly & y $\operatorname{Rar}$ & Standard \\
\hline & & $\begin{array}{l}\text { Production } \\
9469 \\
9797\end{array}$ & Production & $\begin{array}{l}\text { evatian } \\
2097\end{array}$ \\
\hline & 6 & $\begin{array}{r}6080 \\
1091\end{array}$ & $5,096-14,413$ & 920 \\
\hline st $\mathrm{N} . \mathrm{I}$ & I.I. 6 & $\begin{array}{r}10919 \\
7916\end{array}$ & $9,734-12,473$ & 1096 \\
\hline Win & & & $4,757-12,614$ & 2626 \\
\hline
\end{tabular}

from the data in Table 1 the following may be noted:

1. Highest mean yearly pasture productions have 
TABLE 2.

Yearly Productidn of Dry Matter of Pasture Herbage in Several Districts. (Pounds per Acre) Year May/May.

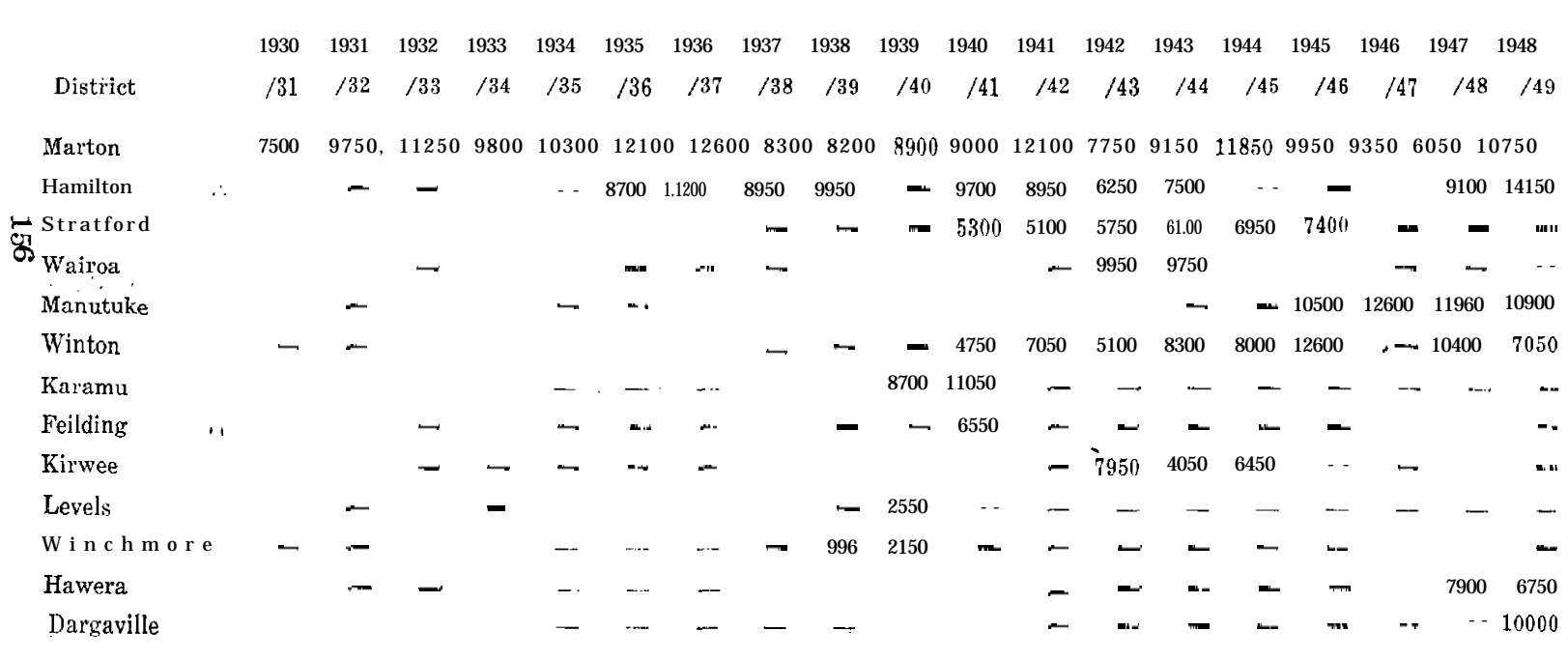


been secured on the alluvial plains at Wairoa and Gisborne (East Coast N.I.) followed. by Marton, Hamilton, Winton, and-Stratford in that order.

2 . The greatest variability in yearly production is seen at Winton, with Hamilton, Marton, East Coast North Island, and Stratford following in that order. The relative consistency of pasture yields at Stratford is associated with the highest mean annual rainfall of the group and the lowest mean yields.

3. The high figures for the East Coast North Island trials may be due to the location of trials on soils less' inclined to dry out than most of the alluvial soils of those districts. Practical experience would indicate much greater variability in total yearly pasture production than Table 1 shows on most of the soils of those districts.

Table 2 shows the complete data available at present. Incomplete information. from districts other than the five considered in Table 1 indicates:

1. On light land in Canterbury (Winchmore and Levels) a yearly dry matter production of about 1,000 $\mathrm{tb}$ in a low production year and 2,000 to 2,500 th in an average, year might be expected. It is interesting to note that irrigation treatments on these trials raised production to as much as three times these figures.

2. On better class, heavier land (Kirwee) in Canterbury, production figures in 3 years ranged from 4,000 ib to nearly 8,000 lb dry matter.

3. Two years' production figures from Hawera are available. In 1947-48 superior production $(7,900 \mathrm{lb})$ to Marton was secured (a record low production year for Marton), and in 1948-49 markedly inferior production $(6,750 \mathrm{lb})$ to Marton, a better-thanaverage year for Marton.

4. In the one year's figures available the production (10,000 th dry matter) from Dargaville in 1948-49 could not be considered very high in view of the favourable season. The trial concerned is located on the fertile Ruawai flats and is on a paspalum-ryegrasswhite clover sward.

2. VARIATION IN SEASONAL PRODUCTION.. IN DIFFERENT 'DISTRICTS

The production figures have been summarised in Table 3 into seasonal periods which. have been taken $\begin{array}{llllllllll}\mathrm{a} & \mathrm{s} & \mathrm{f} & \mathrm{O} & \mathrm{l} & \mathrm{l} & \mathrm{O} & \mathrm{W} & \mathrm{s} & \text { : }\end{array}$ 
Winter: June, July, August

Spring: September, October, November

Summer: December, January, February

Autumn : March, April, May

For each district considered, typical low. production, average production, and high production years have been analysed into the foregoing seasonal periods.

From the foregoing data the following may be noted :

Marton: In a low-production year the pinch is felt in the summer and autumn, whereas in high-production years these periods are characterised by a growth approaching that of the spring months. In the average and below-average years practically 50 per cent. of the yearly production of grass occurs in the three spring months.

Hamilton: The position here is very similar to that at Marton ; the two districts show remarkable similarity in total yearly pasture production and in the spread of production throughout the year.

Stratford: There is little variation in this district in the relative proportions of the seasonal growth to the yearly total in low and high production years, but over the 6 years when grass growth was measured at Stratford the range in yearly productions was remarkably small. The spring growth generally does not form as high a proportion of the total yearly production as at Marton, growth continuing at only a slightly reduced rate into the summer and autumn.

Winton: The difference from North Island conditions at Winton is seen in. the almost complete absence of winter growth. Growth starts late in the spring and carries on well into the summer. In the exceptional year of 1945-46 the feature contributing most to the high production was a marked flush of growth in the summer.

Manutuke: No production data are available for a truly "low" production year,. but the figures for the lowest production year available show a pronounced summer slump in pasture growth. The interesting feature-about this trial, and also the trial at Wairoa; was the exceptionally high winter production.

Kirwee: Only 3 years' figures are available, but 
TABLE 3.

Dry Matter Production of Pastures in 'Seasonal Period (lb/acre)

\begin{tabular}{|c|c|c|c|c|c|c|c|c|c|c|}
\hline District & Year & $\begin{array}{c}\text { Total } \\
\text { Production }\end{array}$ & $\begin{array}{l}\text { W I } \\
\text { Prod. }\end{array}$ & $\begin{array}{l}\mathrm{T} \text { E } \mathrm{R} \\
\text { Prod. as } \\
\% \\
\text { of Total }\end{array}$ & $\begin{array}{l}\text { S P F } \\
\text { Prod. }\end{array}$ & $\begin{array}{l}\mathrm{I} \mathrm{N} \text { G } \\
\text { Prod. as } \\
\mathrm{of}^{\%} \mathrm{Tot} \text { a l l }\end{array}$ & $\begin{array}{l}\text { S U } \\
\text { Prod. } \\
1\end{array}$ & $\begin{array}{l}\text { M E R } \\
\text { Prod. a s } \\
\text { of Total }\end{array}$ & $\begin{array}{l}\text { A. } \mathrm{U} \\
\text { Prod. }\end{array}$ & $\begin{array}{l}\mathrm{M} \mathrm{N} \\
\text { Prod. as } \\
\% \\
\text { of Total }\end{array}$ \\
\hline $\begin{array}{c}\text { Marton (low) } \\
\text { (avge.) } \\
\text { (high) }\end{array}$ & $\begin{array}{l}1947 / 48 \\
1943 / 44 \\
1944 / 45 \\
\end{array}$ & $\begin{array}{r}6055 \\
9149 \\
11854 \\
\end{array}$ & $\begin{array}{r}1961 \\
1280 \\
853 \\
\end{array}$ & $\begin{array}{r}32 \\
14 \\
7 \\
\end{array}$ & $\begin{array}{l}3116 \\
4126 \\
4595 \\
\end{array}$ & $\begin{array}{l}51 \\
45 \\
39 \\
\end{array}$ & $\begin{array}{r}758 \\
2121 \\
3989 \\
\end{array}$ & $\begin{array}{l}13 \\
23 \\
34 \\
\end{array}$ & $\begin{array}{r}220 \\
1622 \\
2417 \\
\end{array}$ & $\begin{array}{r}4 \\
18 \\
20\end{array}$ \\
\hline $\begin{array}{l}\text { Hamilton (low) } \\
\text { (avge.) } \\
\text { (high) }\end{array}$ & $\begin{array}{l}1942 / 43 \\
1941 / 42 \\
1948 / 49\end{array}$ & $\begin{array}{r}6237 \\
8971 \\
14143\end{array}$ & $\begin{array}{l}1025 \\
1280 \\
2713\end{array}$ & $\begin{array}{l}16 \\
14 \\
19\end{array}$ & $\begin{array}{l}3267 \\
3985 \\
5244\end{array}$ & $\begin{array}{l}52 \\
44 \\
3 \mathrm{~s}\end{array}$ & $\begin{array}{l}1708 \\
257 \mathrm{~s} \\
3304\end{array}$ & $\begin{array}{l}27 \\
29 \\
23\end{array}$ & $\begin{array}{r}242 \\
1128 \\
2882\end{array}$ & $\begin{array}{r}3 \\
13 \\
20\end{array}$ \\
\hline $\begin{array}{l}\text { Stratford (low) } \\
\text { (avge.) } \\
\text { (high) }\end{array}$ & $\begin{array}{l}1940 / 41 \\
1943 / 44 \\
1945 / 46\end{array}$ & $\begin{array}{l}5272 \\
6081 \\
7413\end{array}$ & $\begin{array}{l}500 \\
888 \\
377\end{array}$ & $\begin{array}{r}9 \\
15 \\
5\end{array}$ & $\begin{array}{l}1943 \\
1854 \\
3231\end{array}$ & $\begin{array}{l}37 \\
30 \\
44\end{array}$ & $\begin{array}{l}1900 \\
1759 \\
2199\end{array}$ & $\begin{array}{l}36 \\
29 \\
30\end{array}$ & $\begin{array}{r}922 \\
1580 \\
1606\end{array}$ & $\begin{array}{l}18 \\
26 \\
21\end{array}$ \\
\hline $\begin{array}{c}\text { Winton (low) } \\
\text { (avge.) } \\
\text { (high) }\end{array}$ & $\begin{array}{l}1942143 \\
1941 / 42 \\
1945 / 46\end{array}$ & $\begin{array}{r}5100 \\
7050 \\
12614\end{array}$ & $\begin{array}{l}215 \\
492\end{array}$ & $\overline{3}$ & $\begin{array}{l}2003 \\
2852 \\
3279\end{array}$ & $\begin{array}{l}40 \\
26\end{array}$ & $\begin{array}{l}2042 \\
2371 \\
6645\end{array}$ & $\begin{array}{l}40 \\
34 \\
53\end{array}$ & $\begin{array}{l}1055 \\
1612 \\
2198\end{array}$ & $\begin{array}{l}21 \\
23 \\
17\end{array}$ \\
\hline $\begin{array}{c}\text { Manutuke (low) } \\
\text { (avge.) } \\
\text { (high) }\end{array}$ & $\begin{array}{l}1945 / 46 \\
1948 / 49 \\
1946 / 47\end{array}$ & $\begin{array}{l}10505 \\
10944 \\
12473\end{array}$ & $\begin{array}{l}2259 \\
2859 \\
1585\end{array}$ & 26 & $\begin{array}{l}4362 \\
3219 \\
4009\end{array}$ & $\begin{array}{l}42 \\
29 \\
32\end{array}$ & $\begin{array}{l}1667 \\
3735 \\
3306\end{array}$ & $\begin{array}{l}16 \\
34 \\
27\end{array}$ & $\begin{array}{l}2217 \\
1131 \\
3573\end{array}$ & $\begin{array}{l}21 \\
11 \\
29\end{array}$ \\
\hline $\begin{array}{c}\text { Kirwee (low) } \\
\text { (avge.) } \\
\text { (high) }\end{array}$ & $\begin{array}{l}1943 / 44 \\
1944 / 45 \\
1942 / 43\end{array}$ & $\begin{array}{l}4063 \\
6454 \\
7976\end{array}$ & $\begin{array}{l}579 \\
533 \\
616\end{array}$ & $\begin{array}{r}14 \\
8 \\
8\end{array}$ & $\begin{array}{l}1402 \\
2126 \\
2963\end{array}$ & $\begin{array}{l}35 \\
33 \\
37\end{array}$ & $\begin{array}{l}1140 \\
2861 \\
1320\end{array}$ & $\begin{array}{l}28 \\
44 \\
17\end{array}$ & $\begin{array}{r}942 \\
934 \\
3077\end{array}$ & $\begin{array}{l}23 \\
15 \\
38\end{array}$ \\
\hline $\begin{array}{c}\text { Winchmore (low) } \\
\text { (avge.) }\end{array}$ & $\begin{array}{l}1939 / 40 \\
1940 / 41\end{array}$ & $\begin{array}{r}992 \\
2132\end{array}$ & $\overline{170}$ & $\overline{8}$ & $\begin{array}{r}594 \\
1400\end{array}$ & $\begin{array}{l}60 \\
66\end{array}$ & $\begin{array}{l}330 \\
201\end{array}$ & $\begin{array}{r}33 \\
9\end{array}$ & $\begin{array}{r}68 \\
361\end{array}$ & $\begin{array}{r}7 \\
17\end{array}$ \\
\hline Dargaville & $1948 / 49$ & 10004 & '2415 & 24 & 3703 & 37 & 2677 & 27 & 1209 & 12 \\
\hline
\end{tabular}


TABLE 4.

Rainfall Totals in Seasonal and Yearly Periods in Various Districts (in.)

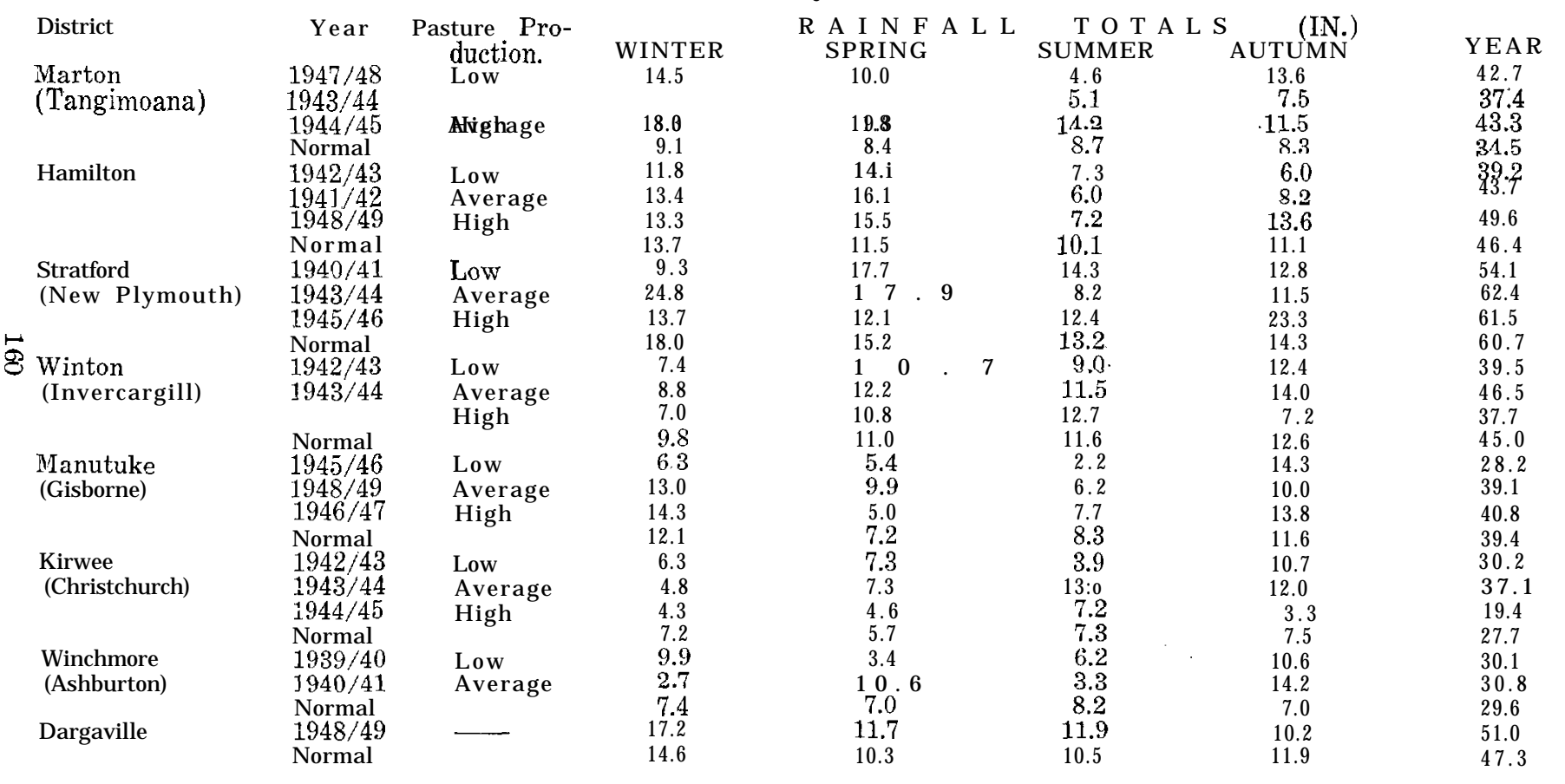


these show in the lowest production year a continuation of spring. pasture- production, but at a relatively . low level, into the summer and: autumn. When the spring growth was better, however, a slump in growth occurred either in the summer or in the autumn. Winter growth is small and it would appear that pasture growth at any season is, unreliable.

Winchmore: With- two years' figures. only, it is clear that spring growth dominates yearly production to a much greater extent than in other districts. If this fails, yearly production is very low indeed.

Dargaville: The only year for which pasture production figures are available shows a good spread of production in winter, spring, and summer, with some falling off in the autumn.

\section{RELATION OF. SEASONAL PASTURE PRO- DUCTION TO RAINFALL}

Table 4 summarises the rainfall. totals ${ }^{6}$ in seasonal and yearly periods in a "low," an "average," and a "high" grassland production year in the districts considered.

The comparison of rainfall with production (Tables 2 and 3 ) shows that the total yearly rainfall bears little relation to the total yearly production of grass. Furthermore, the winter rainfall appears to have little 'effect on winter pasture production, but the data in low rainfall districts is not sufficient to enable this to be firmly established in those areas.

Spring rainfall shows the least variation and generally is not closely associated with production variations except at Winchmore on light land where a low spring rainfall was associated with low spring-and yearly pasture production despite better. rains in the summer and autumn following.

Summer rainfall (December, January, and February) appears to be the most variable and to be closely correlated with summer pasture production. Significant positive correlation co-efficients have been established between pasture production and rainfall totals for these three months for the data in Tables' 2 and 3. For "high-producing" districts (Marton, Hamilton, and Manutuke) the value is $r=\mathbf{0 . 6 6 5}$, while for the remaining districts the value $r=0.648$ was found. Expressed in terms of the increase in production of dry matter of herbage for each inch of rainfall 'for the -threemonthly totals the values of $\mathbf{2 2 2} \mathbf{\mathbf { m b }}$. dry matter. for 
high-producing districts and $288 \mathrm{tb}$ dry matter of pasture herbage for the remaining districts were calculated. However, this difference is not statistically significant.

The autumn rainfall appears to be more consistent than the summer and to be less closely associated with pasture production. The period considered as autumn extends to the end of May, by which time summer dry spells have usually been broken and temperature is becoming the critical factor. The correlation between rainfall and production would no doubt be closer in the early autumn months.

Temperature has a marked effect on production and earlier work based on the Ruakura trials (3) showed good correlation between both soil (4 inches) and screen maximum temperatures and pasture production during periods when moisture was not a limiting factor.

\section{SEASONAL PRODUCTION OF SEVERAL PAS-} TURE SPECIES

One of the most valuable features of pasture growth rate data is the examination. of the contribution to total production made by the various elements of the sward at different seasons of the year. Species production figures are obtained from dissections of the mown herbage into species components. The relative proportions of each species present can be determined by weighing on a dry matter basis and the production of such species can be estimated by applying such percentage data to the total dry matter production figures. Species dissection analyses up to 1947 were carried out by the Grasslands Division, Department of Scientific and Industrial Research, and since that year by the Rukuhia Soil Fertility Research Station, Department of Agriculture, Hamilton.

For the following material trials at various centres have been taken whose swards contained appreciable amounts of each species considered. In most cases such trials are not those analysed previously in this paper.

\section{Perennial Ryegrass (Graph 2)}

As the dominant species in a sward perennial ryegrass is one of the first grasses to come away in

(3) Lynch, P. B.-Yields and Compositions of Pastures on Certain Soil Types in the Waipa County, N.Z., as influenced by Season and
Fertilizer. Unpublished Thesis; 1938 . 
the spring. At Marton growth usually commences in early September and is at a maximum in October and November. "A marked falling-off in production usually occurs during December, January, and February, and autumn recovery in March or April is dependent on

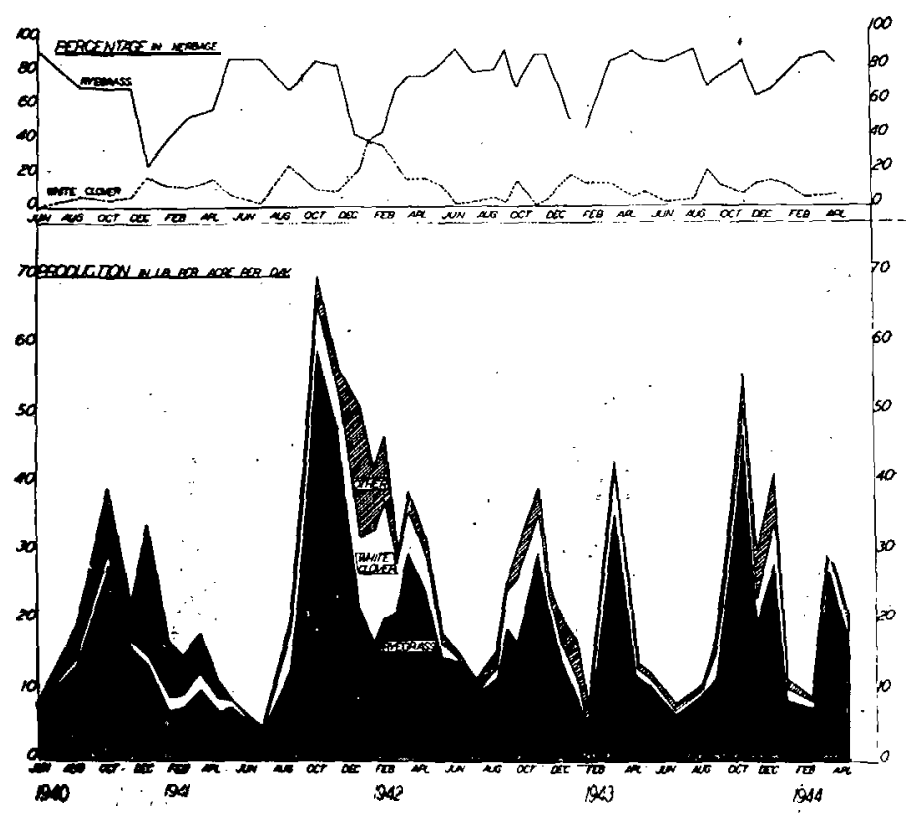

Graph 2.-Ryegrass and white clover. Seasonal changes in growth rate and percentage in herbage. Trial 0, Marton.

rainfall. Graph 4 illustrates the extreme variability of the summer and autumn production of perennial ryegrass. In the 1940-41 season autumn growth failed; in 1941-42 it was substantial, 'while in 1942-43 it equalled spring production.

Expressed as a percentage, of the mown herbage, perennial ryegrass is at its lowest in the summer and highest in the winter and spring.

White Clover (Graph 2)

Herbage production of white clover is small except during the summer and autumn. The percentage of white clover in the mown herbage follows a similar trend. In a sward that by ground cover estimation was a first-class balance between perennial ryegrass and white clover, the actual production from white clover is surprisingly small. The large amount of evidence available shows that dominant clover swards are usually low-producing. 


\section{Timothy (Graph 3)}

In a sward at Marton dominantly perennial. ryegrass with much red and white clover and Poa trivialis, timothy has shown the following features with regard to production:-

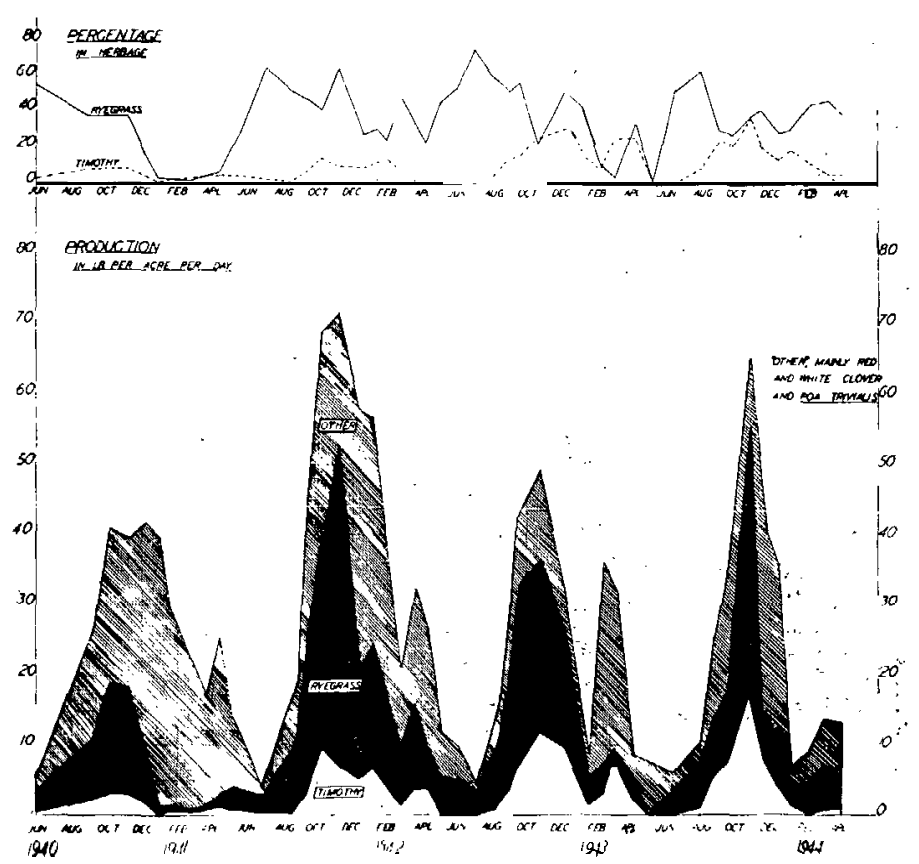

Graph 3.-Timothy. Seasonal changes in growth rate and percentage

1. It is later in growth than perennial ryegrass in the spring by about a month.

2. Winter production is negligible and from June to August is relatively much less than that of perennial ryegrass.

3. The "summer slump" in production is less pronounced than with perennial ryegrass.

4. As a percentage of the mown herbage timothy is prominent in the months October to April.

Timothy-dominant swards at Marton in 194'7-48 yielded about 80 per cent. of that of ryegrass-dominant swards: in 1948-49 the figures was 88 per cent. However, the production of the sward of Graph 5 where timothy was sub-dominant to perennial ryegrass was slightly better than a comparable ryegrass-white clover sward without timothy. This may have been 
due to the more lenient grazing that was required to maintain timothy in'the sward;

Cocksfoot (Graph 4)

In a cocksfoot-dominant sward at Marton the outstanding feature was the late summer and autumn production of cocksfoot, which in most years approxi-

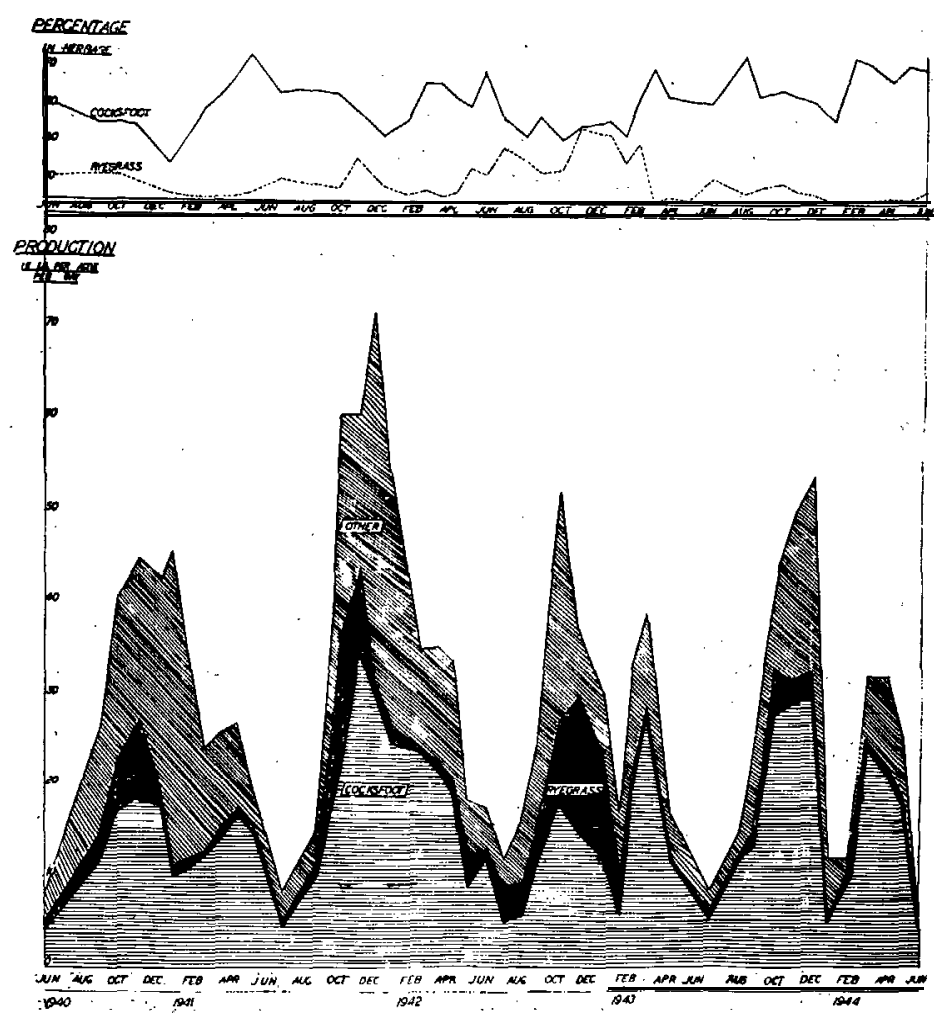

Graph 4.-Cocksfoot. Seasonal changes i n growth rate and. p e r c e n t a g e

mated the spring production of that species. In contrast, perennial ryegrass gives the bulk of its growth in'the spring. Winter growth of cocksfoot is good, but in each season except that of 1941-42 production slumps in January and February only to recover again in "late summer and autumn. This mid-summer drop in, production coincides with a lower percentage of cocksfoot in the mown' herbage. Apart from this period the proportion of cocksfoot in the herbage is relatively consistent. 
Total pasture production of this cocksfoot-dominant sward was slightly better than 'a comparable perennial ryegrass-dominant sward, but again this, may have associated with more lenient grazing.

The "other" species shown in Graph 6 were mainly Yorkshire fog and red and white clover.

Yorkshire Fog (Graph 5)

At Stratford the growth rate of Yorkshire fog throughout the yearshows less variation than that of many other species. The striking feature of this species is its winter production, which is most clearly seen in considering the percentage present in the mown herbage. This figure rises to a maximum in the late winter and early spring in most years.
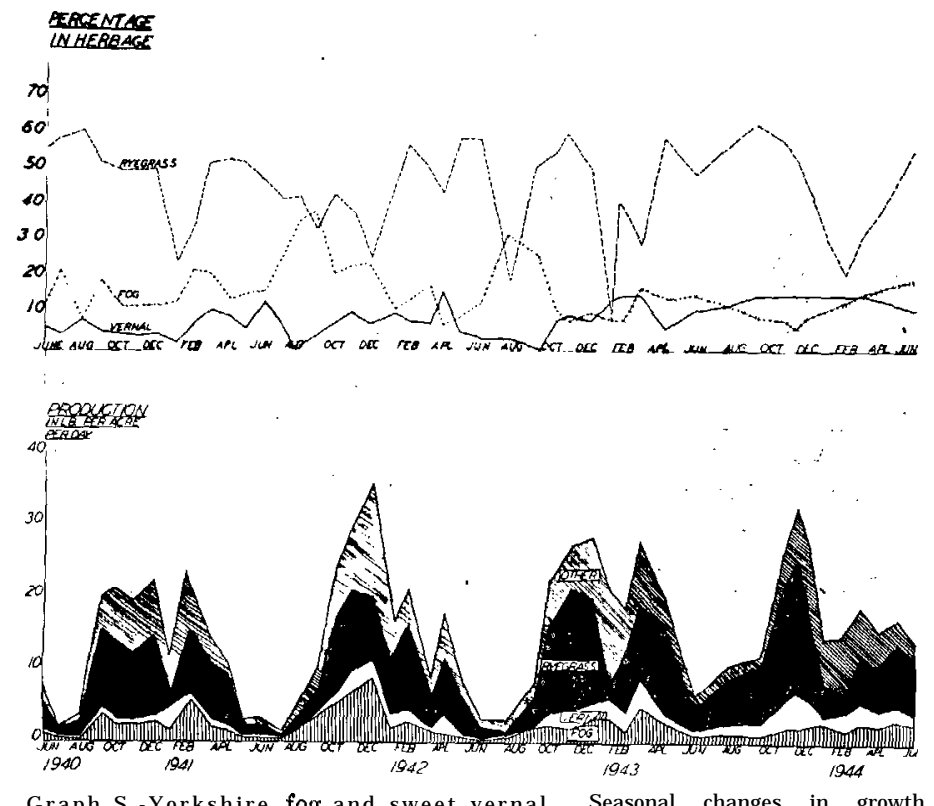

Graph S.-Yorkshire fog and sweet vernal. Seasonal changes in growth rate and percentage in herbage, Stratford.

Nevertheless evidence from Marton trials shows that total pasture production declines when Yorkshire fog-increases, although this effect is complicated by the fact that the main reason for increasing amounts of Yorkshire fog is declining fertility. On an untopdressed sward at Marton now dominantly Yorkshire fog, production is now only half that of- adjacent topdressed ryegrass-white clover swards. 


\section{Sweet Vernal (Graph 5)}

Although sweet vernal is present in the, sward in considerable -amounts at Stratford $\{$ its contribution to production has been small. The interesting point is, however, that,. except for the 1943-44 season, sweet vernal is prominent when Yorkshire fog is in relatively small proportion in the mown herbage, and vernal practically disappears in the winter and early spring when fog shows to best advantage;

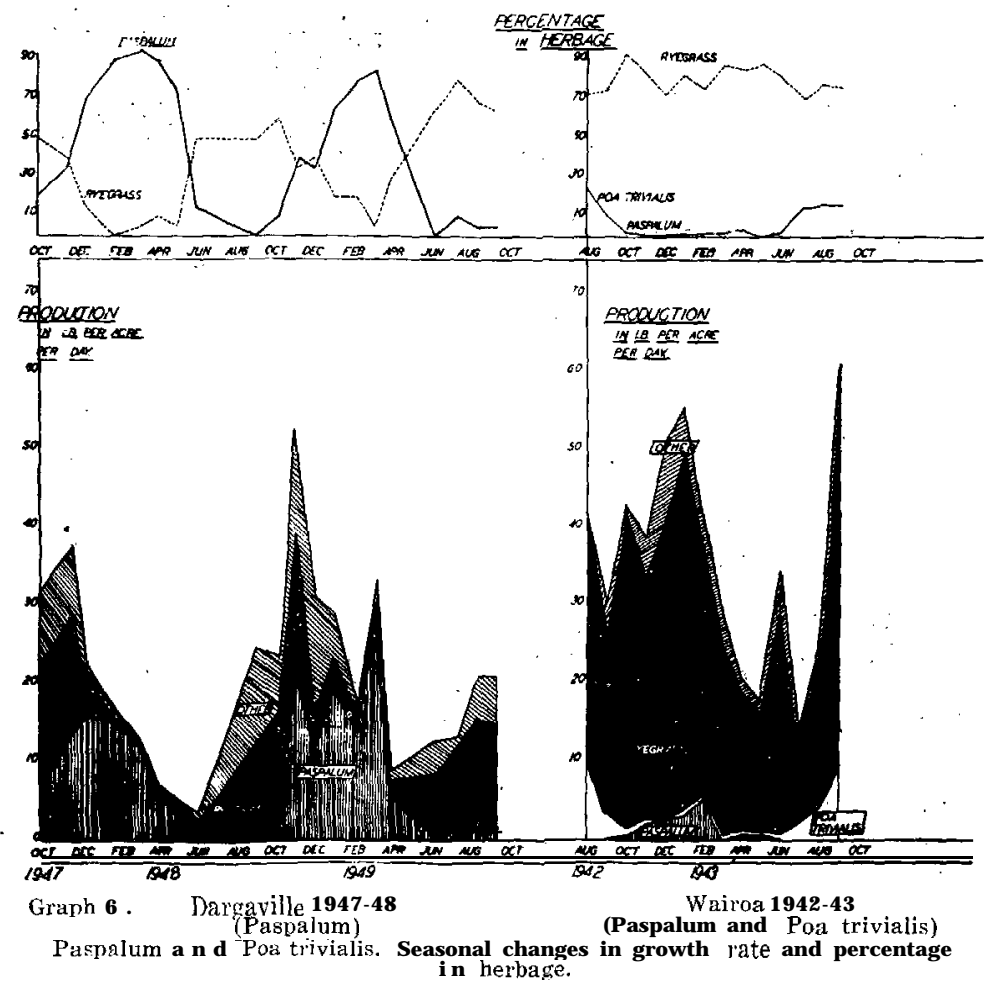

\section{Paspalum (Graph 6)}

... At Dargaville on a sward where perennial rye\&ass and'paspalum alternately dominate, the proportion of one of these species in the mown herbage varies inversely with that of the other. Paspalum growth occurs mainly from November to April, while perennial ryegrass is dominant in the winter and early spring. The autumn growth is practically pure paspalum.

The two years' production figures available from Dargaville do not show the summer slump in pasture 
production to nearly the extent seen in other swards in other districts.

At Wairoa where a small amount of paspalum in the sward was greatly overshadowed by ryegrass growth the production period of paspalum was from November to March in one season only.

\section{Poa trivialis (Graph 6)}

From the limited evidence of one year's figures from Wairoa, it would appear that Poa trivialis is a winter producer, making practically all its growth in the June-October period. At other periods of the year Poa trivialis ceases growth and is replaced by ryegrass and possibly paspalum in the Wairoa trial.

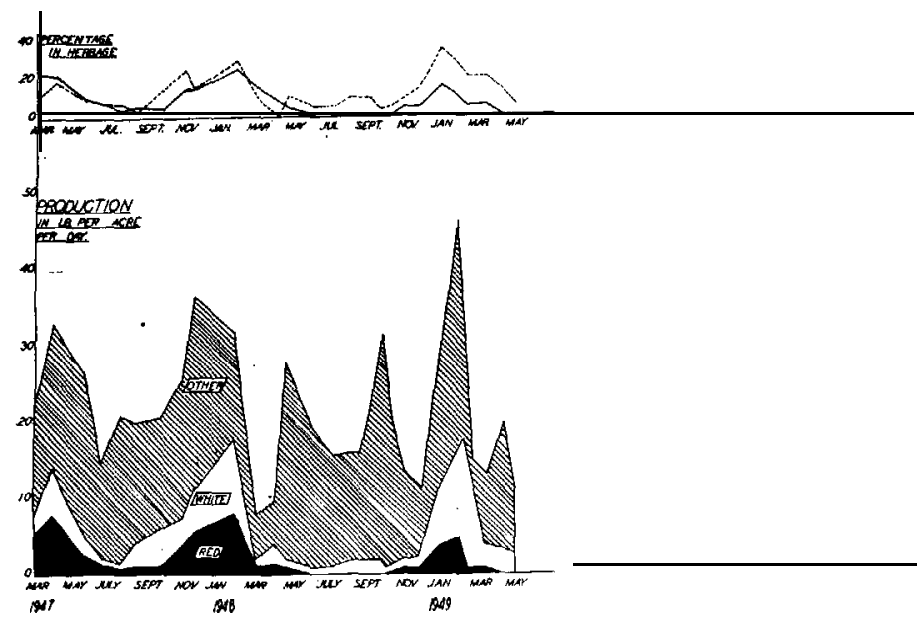

Graph 7.-Red Clover. Seasonal changes in growth rate and percentage

\section{Red Clover (Graph 7)}

At Waimate West the season for red clover growth extends from November to May, but except in 1947 the maximum growth period was from November to February only. White clover gives more winter and spring production than red clover, but both species contribute most towards pasture production in the summer months.

Graph 7 shows an exceptionally high level of winter production in two seasons at Waimate West (Hawera). 


\section{SUMMARY}

I have briefly outlined the type of data that. is being accumulated from, pasture rate-of-growth trials. The application of the data to the practical problems of the farmer and of the research worker will be sufficiently obvious. The agricultural production of New Zealand is based on the productivity of her pastures. Surely a study of pasture production is worth while in any case, but particularly when the unreliability of the grass crop can be demonstrated. The comparatively steady demand of the grazing animal superimposed on highly variable pasture production will always create problems of stock husbandry and of the provision of supplementary feed, whether of conserved pastures or special crops. 